\title{
Estrogen mimicking effects of xenobiotics in fish
}

\author{
Poul Bjerregaard \\ From Environmental contaminants and animal health. The 26th Symposium of the Nordic Committee for \\ Veterinary Scientific Cooperation (NKVet) \\ Helsinki, Finland. 6-7 October 2011
}

Sex hormones produced in humans and livestock are excreted in the urine. Naturally produced and synthetic contraceptive pill estrogens may pass low-quality waste water processing plants and feminize male fish in streams and coastal areas downstream such discharges $[1,2]$. High-quality processing of the wastewater with tertiary treatment, nutrient removal and sufficient water and sludge retention times basically removes the problem $[3,4]$.

The feminization of male fish downstream waste water discharges has mainly been demonstrated by the presence of elevated levels of female yolk protein (vitellogenin) in the blood of male or juvenile fish or eggs (or oocytes) in the testes (intersex) [5]. Both of these phenomena are used as biomarkers for estrogenic effects and as always in the use of biomarkers, it is important to define the natural background level in an uncontaminated environment.

The first investigations on intersex in roach showed that male fish in areas not directly affected by wastewater discharges had intersex percentages between 5 and $11 \%[1,6]$, suggesting that there might be a low, natural occurrence of this phenomenon. Recent investigations [7] in pristine areas do, however, show no intersex among the males, indicating that the natural background level of intersex roach may actually be zero.

Plasma levels in male or juvenile fish have been used as an efficient biomarker to detect estrogenic contamina-tion in both freshwater and marine areas and a number of studies [e.g. [8,9]] have presented vitellogenin levels that are markedly and unambiguously elevated - maybe several orders of magnitude - compared to background levels. Less effort has been devoted to defining when less severe increases in plasma vitellogenin levels actually indicate a difference relative to unaffected background levels [10]. The occurrence of intersex in roach and elevated vitellogenin levels in areas not directly affected by discharges

\footnotetext{
Institute of Biology, University of Southern Denmark, Campusvej 55, DK-5230
} Odense M, Denmark from sewage treatment plants suggests that there may be other inputs of estrogenic activity to the aquatic environment and, in fact, several possibilities - some of them associated with intensive, modern agriculture - exist.

Estrogens have been found to leach to the water draining from fields treated with pig manure [11], which generally has a high content of especially estrone and estrogenic activity has been found in streams in connection with dairy cattle farms [12].

Leguminous plants - such as clover, peas, lupine and alfalfa used as nitrogen binding crop in e.g. organic farming - produce phytoestrogens which may leach to - and are detected in - the freshwater environment [13] - most often in the ng/l range. Some phytoestrogens induce vitellogenin synthesis in the low $\mu \mathrm{g} / \mathrm{l}$ range [14].

Houses in the open land are not all connected to central sewage treatment plants and simple waste water processing measures such as septic tanks may be employed. Septic tanks do a very poor job removing estrogens from wastewater and estrogenic activities 20 times higher than needed to feminize brown trout have been detected in discharges from such systems [15].

Recently, exposure to $17 \beta$-estradiol and octylphenol has been shown to cause malformations in embryos of viviparous eelpout at fairly high - but still environmentally realistic concentrations [16].

\section{Published: 24 February 2012}

\section{References}

1. Jobling S, Nolan M, Tyler CR, Brighty G, Sumpter JP: Widespread sexual disruption in wild fish. Environ Sci Technol 1998, 32:2498-2506.

2. Matthiessen P: Endocrine disruption in marine fish. Pure App/ Chem 2003, 75:2249-2261.

3. Andersen $H$, Siegrist $H$, Halling-Sorensen $B$, Ternes TA: Fate of estrogens in a municipal sewage treatment plant. Environ Sci Technol 2003, 37:4021-4026.

4. Stuer-Lauridsen F, Kjølholt J, Høibye L, Hinge-Christensen S, Ingerslev F, Hansen $M$, et al: Survey of estrogenic activity in the Danish aquatic environment. Environmental Project 977 Danish EPA; 2005, 1-170. 
5. Jobling S, Tyler CR: Endocrine disruption in wild freshwater fish. Pure App/ Chem 2003, 75:2219-2234.

6. Bjerregaard LB, Korsgaard B, Bjerregaard P: Intersex in wild roach (Rutilis rutilis) from Danish sewage effluent-receiving streams. Ecotoxicol Environ Saf 2006, 64:321-328.

7. Geraudie P, Gerbron M, Hill E, Minier C: Roach (Rutilus rutilus) reproductive cycle: a study of biochemical and histological parameters in a low contaminated site. Fish Physiol Biochem 2010, 36:767-777.

8. Harries JE, Sheahan DA, Jobling $S$, Matthiessen $P$, Neall M, Sumpter JP, et al: Estrogenic activity in five United Kingdom rivers detected by measurement of vitellogenesis in caged male trout. Environ Toxicol Chem 1997, 16:534-542.

9. Kirby MF, Allen YT, Dyer RA, Feist SW, Katsiadaki I, Matthiessen P, et al: Surveys of plasma vitellogenin and intersex in male flounder (Platichthys flesus) as measures of endocrine disruption by estrogenic contamination in United Kingdom estuaries: Temporal trends, 1996 to 2001. Environ Toxicol Chem 2004, 23:748-758.

10. Bjerregaard P, Hansen P, Larsen KJ, Erratico C, Korsgaard B, Holbech H: Vitellogenin as a biomarker for oestrogenic effects in brown trout, Salmo trutta: Laboratory and field investigations. Environ Toxicol Chem 2008, 27:2387-2396.

11. Kjaer J, Olsen P, Bach K, Barlebo HC, Ingerslev F, Hansen M, et al: Leaching of estrogenic hormones from manure-treated structured soils. Environ Sci Technol 2007, 41:3911-3917.

12. Matthiessen P, Arnold D, Johnson AC, Pepper TJ, Pottinger TG, Pulman KGT: Contamination of headwater streams in the United Kingdom by oestrogenic hormones from livestock farms. Sci Total Environ 2006, 367:616-630

13. Ribeiro C, Tiritan ME, Rocha E, Rocha MJ: Seasonal and spatial distribution of several endocrine-disrupting compounds in the Douro River Estuary, Portugal. Arch Environ Contam Toxicol 2009, 56:1-11.

14. Bjerregaard P, Schröder KD, Nielsen ML, Brande-Lavridsen N, Holbech $H$ : Estrogenic effect of biochanin A in zebrafish Danio rerio and brown trout Salmo trutta. In prep 2011.

15. Stuer-Lauridsen F, Kjølholt J, Høibye L, Hinge-Christensen S, Ingerslev F, Hansen M, et al: Survey of estrogenic activity in the Danish aquatic environment- B. Environmental Project 1077 Danish EPA; 2006, 1-49.

16. Bjerregaard P, Brande-Lavridsen N, Nielsen RV, Rasmussen TH, Korsgaard B: A novel type of endocrine disrupting effect: Octylphenol and 17 $\beta$ estradiol cause abnormal development in embryos of the viviparous eelpout Zoarces viviparus. In prep 2011.

doi:10.1186/1751-0147-54-S1-S12

Cite this article as: Bjerregaard: Estrogen mimicking effects of xenobiotics in fish. Acta Veterinaria Scandinavica 2012 54(Suppl 1):S12.

\section{Submit your next manuscript to BioMed Central and take full advantage of:}

- Convenient online submission

- Thorough peer review

- No space constraints or color figure charges

- Immediate publication on acceptance

- Inclusion in PubMed, CAS, Scopus and Google Scholar

- Research which is freely available for redistribution

Submit your manuscript at www.biomedcentral.com/submit
C Biomed Central 